•综述・

\title{
动物对孢子植物的传播模式及进化意义
}

\author{
王琴 ${ }^{(1} 1$, 陈远 ${ }^{2}$, 禹洋 $1^{*}$, 向左甫 ${ }^{1 *}$
}

1. 中南林业科技大学生命科学与技术学院, 长沙 410004; 2. 中山大学生命科学学院, 广州 510275

摘要: 孢子植物物种多样性丰富, 是自然生态系统的重要组成部分。孢子植物的传播通常被认为主要依靠风、水、弹力等非 生物媒介, 而动物的作用往往被忽略。本文主要概述了: (1)孢子植物对动物传播的适应: 一方面孢子植物可为动物提供食物、 庇护所、繁殖场所等, 另一方面孢子植物也可产生视觉、嗅觉等方面的线索来吸引动物, 从而促进动物传播其繁殖体。(2)动 物对孢子植物的传播模式: 包括体内传播(消化道和组织寄生)和体外传播两种, 这些模式都能对狍子植物繁殖体进行有效传 播。由于动物间形态或生活习性的不同, 以致传播距离存在差异, 最短距离为 $0.1 \mathrm{~cm}$, 最长距离可从北半球至南半球。(3)动 物对孢子植物传播的生态与进化意义; 由于某些孢子植物繁殖体的结构特点或萌发的需求，以致其繁殖体只能通过动物的传 播才能得以定殖, 因此动物与孢子植物之间存在密不可分的关系。目前, 动物对孢子植物的传播研究主要是描述性的内容以 及研究单方面的传播途径，建议在今后的研究中考虑动物对孢子植物传播的有效性以及多途径同时传播对孢子植物定殖的 影响，同时应更加关注孢子植物和动物互惠关系的形成、维持机制及将来的进化趋势。

关键词: 孢子植物; 动物传播; 互惠关系; 植被更新; 生物多样性保护

王琴, 陈远, 禹洋, 向左甫 (2021) 动物对孢子植物的传播模式及进化意义. 生物多样性, 29, 995-1001. doi: 10.17520/biods.2020449. Wang Q, Chen Y, Yu Y, Xiang ZF (2021) Dispersal of spore plants by animals: Patterns and evolutionary significance. Biodiversity Science, 29, 995-1001. doi: 10.17520/biods.2020449

\section{Dispersal of spore plants by animals: Patterns and evolutionary significance}

\author{
Qin Wang ${ }^{\mathbb{D}_{1}}$, Yuan Chen ${ }^{2}$, Yang $\mathrm{Yu}^{\mathrm{u}^{*}}$, Zuofu Xiang ${ }^{\mathbb{D}_{1 *}}$
}

1 College of Life Science and Technology, Central South University of Forestry and Technology, Changsha 410004

2 School of Life Sciences, Sun Yat-sen University, Guangzhou 510275

\begin{abstract}
Background \& Aims: Spore plants, as an important food source for terrestrial animal, play a vital role in maintaining the subtle balance of the earth's ecological system. Animals and spore plants may also together form an interaction system similar to the network of zoochorous seed dispersal. Therefore, the effect of animals on spore plant propagules dispersal has been receiving increasing attention. Here, we summarize that (1) the adaptation of spore plants to dispersal by animals. On the one hand, spore plants can provide food, shelters and breeding sites for animals; on the other hand, spore plants can also produce visual and/or olfactory cues and so on to attract animals in order to increase their propagule dispersal. (2) the two zoochorous dispersal patterns of spore plants that can effectively disperse propagules of spore plants, namely endozoochory (through the digestive tract and parasitism) and epizoochory. Due to the different morphological characteristics and life habits between animals, the distance of dispersal is also different, with the shortest distance of $0.1 \mathrm{~cm}$ and the longest distance from the northern hemisphere to the southern hemisphere. (3) The ecological and evolutionary meanings of zoochorous dispersal of spore plants. For some spore plant propagules, due to their special structural characteristics or particular need for germination, the propagules can only be dispersed by specific animals, which leads to an inseparable relationship between such animals and spore plants.

At present, few studies in this field have been conducted in China. The researches on spore plant dispersal in other countries are mainly descriptive, most of which are independent pattern on spore plant dispersal.
\end{abstract}

Prospects: We propose that more consideration should be given to the multi-pattern dispersal and mutualistic

收稿日期: 2020-12-05; 接受日期: 2021-03-09

基金项目: 国家自然科学基金(31870509; 31670397)

* 共同通讯作者 Co-authors for correspondence. E-mail: yuyangjcl@126.com; xiangzf@csuft.edu.cn 
relationship between animals and spore plants in future studies, as well as the formation, maintenance mechanism and future evolutionary trends of spore plant-animal relationships.

Key words: spore plants; zoochorous dispersal; mutualistic relationship; vegetation regeneration; biodiversity conservation

孢子植物旧称隐花植物，不产生种子，生活史 中通过产生孢子的方式完成后代繁殖。生物群落中 的藻类、菌类、地衣、苔藓和䓲类均属于孢子植物 (罗健馨, 1977)。孢子植物是许多陆生动物的重要食 源(Bråthen et al, 2007; Boch et al, 2011)。虽然狍子植 物不像被子植物那样有着鲜艳的花、果实、种子来 吸引动物, 但是某些孢子植物(如菌类、苔藓)能够产 生特殊的气味(Tuno, 1998; Fischer \& Vicha, 2003; Marino et al, 2009; Chen et al, 2014), 或者满足动物 需求(如筑巢)来吸引传播者 (Chmielewski et al, 2019), 还有一些特殊的孢子植物能够感染蚂蚁并 寄生于蚂蚁体内(Gracia et al, 2018), 因此它们的繁 殖体能够被不同的动物传播。但由于很少有研究涉 及动物对孢子植物的传播, 以致于动物-孢子传播 系统远不如花粉、种子传播互作系统清楚。近年来, 一些研究涉及到了不同动物-孢子植物互作系统: (1) 鸟类长距离传播有活力的种子同时可传播从枝菌 根真菌的繁殖体, 揭示了从枝菌根真菌全球性分布 的一种重要扩散机制(Correia et al, 2019); (2)尽管某 些无脊椎动物, 如苍蝇(Marino et al, 2009)和蚂蚁 (Rudolphi，2009)也能传播苔藓植物的无性繁殖体, 但苔藓植物的传播主要依赖脊椎动物, 如啮齿类 (Kimmerer \& Young, 1996; Arosa et al, 2010; Barbé et al, 2016; Stephens \& Rowe, 2020)和岛类(如绿头 鸭Anas platyrhynchos和凤头麦鸡Vanellus vanellu) (Wilkinson et al, 2017); (3)䓲类植物的传播出现在北 欧驯鹿(Rangifer tarandus tarandus) (Bråthen et al, 2007)、蚯蚓(van Tooren \& During, 1988)、家蟋蟀 (Acheta domesticu)、甘蓝夜蛾(Mamestra brassicae) (Boch et al, 2016)等动物中; (4)地衣(真菌和藻类的 共生体) 也被某些动物传播, 如: 皇信天翁 (Diomedea epomophora)、乌冻(Turdus merula)、欧 亚鸲(Erithacus rubecula) (Bailey \& James, 1979)以 及一些无脊椎动物, 如蛞蝓 (Agriolimax agrestis) (Boch et al, 2016)和蜗牛(Boch et al, 2011)等。

动物生活环境以及物种特征差异使孢子植物 的传播受到了多因素的影响, 如动物行为特征、传
播方式以及传播后的萌发情况等。本文回顾了近年 来有关动物对孢子植物传播的研究, 分析了动物对 孢子植物的传播方式及其生态过程, 期望提高公众 对动物传播孢子植物的认识, 加深理解动植物关系 以及动物对植被更新的作用。

\section{孢子植物对动物传播的适应}

根据生活史特征, 孢子植物的繁殖方式一般分 为两种: 有性繁殖和无性繁殖。有性繁殖即植物(原 叶体)产生具有繁殖和休眠作用的孢子, 孢子在适 宜条件下能直接发育成新个体; 无性繁殖(营养繁 殖)则主要通过植物(叶状体)的断裂等形成裂芽或 碎片而发育成新个体(Maciel-Silva \& Pôrto, 2014), 孢子植物的孢子或者无性繁殖体均可被动物传播 (Johnson \& Jürgens, 2010; Pauliuk et al, 2011)。

有些孢子植物可产生视觉、嗅觉等方面的线索 (如模仿动物的食物或繁殖位点)来吸引动物, 从而 利用动物帮助其传播繁殖体(图1)。如一些真菌能产 生假花, 在形状、大小、颜色、气味上模仿真花, 当 鸟类受食时, 孢子粘附其喙上, 从而得到传播(Roy, 1994; Kaiser, 2006); 还有某些苔藓植物的孢子体通 过模仿腐烂的有机物来吸引昆虫, 这些有机物是苍 蝇幼虫的食物(Salzmann et al, 2006)。甚至还有一些 苔藓植物的幼芽能够产生化合物从而吸引以苔藓 植物精子为食的弹尾虫, 以此辅助苔藓植物受精, 这类似于被子植物的花粉被动物取食与传播 (Bisang \& Hedenäs, 2015)。

孢子植物能够吸引动物的一部分原因是植物 的“欺骗”行为, 另一部分原因是为一些动物提了供 食物、庇护(Gressitt et al, 1968)和繁殖场所等, 例如 苔藓植物可以作为鸟类的食物和筑巢材料 (Chmielewski et al, 2019)。除此之外, 某些孢子植物 由于季节性变化小, 能够成为动物的过渡性食物, 如在食物圆乏季节, 中国的几种金丝猴 (Rhinopithecus spp.)会大量取食松萝、苔藓等孢子植 物(向左甫, 2020), 松夢含有较高的钙元素。一些植 物的孢子可为动物提供热量, 例如, 小林姬鼠 
(Apodemus sylvaticus) 只取食垫囊蕨科的 Culcita macrocarpa, 它的叶子具有丰富的孢子囊群, 孢子 富含脂质和蛋白质(Arosa et al, 2009), 可在冬季为 小林姬鼠提供充足的能量资源(Arosa et al, 2010)。

\section{动物对孢子植物的传播过程}

动物和孢子植物也可能形成与种子植物传播 网络相似的互作系统, 因此动物对孢子植物繁殖体 的传播作用日益受到关注, 这些传播途径对狍子植 物的种群更新有着重要影响(Barbé et al, 2016)。许 多学者以体外传播和体内传播作为切入点, 对一些 潜在的动物类群(传播者)开展了研究。

\section{1 传播模式}

动物对于孢子植物的传播模式可分为体外传 播(epizoochory)和体内传播(endozoochory) (图1)。

(1)体外传播模式, 即植物繁殖体附着于动物 的体表或毛发, 随着动物的日常活动而被传播到新 生境。如在干燥草原上休息过的绵羊(Ovis aries), 皮毛中携带了16种苔藓植物的繁殖体和1种枝状地 衣碎片(Pauliuk et al, 2011), 一些苔蘚植物物种即使 是小于 $1 \mathrm{~mm}$ 的碎片也很容易再生形成成熟的植物 (Mishler \& Newton, 1988)。绝大多数携带有真菌孢 子的鸟类也携带有花粉粒, 这说明它们是以花朵为 食, 并且花粉与真菌孢子形成协同分散, 孢子并非 随机分散到环境中, 而是可能沉积在有利于真菌发 育的花上(da Silva et al, 2016)。更神奇的是, 有些真 菌和苔藓利用 “诱骗”的方式吸引动物帮其传播孢子, 例如一些苔藓的孢子体与 “臭角”真菌 (“stinkhorn” fungi) 通过模仿苍蝇的食物和孵化地来吸引苍蝇
(Fischer \& Vicha, 2003; Marino et al, 2009), 粘稠的 孢子附着在苍蝇体表进行传播，并且研究发现“臭 角”真菌和某些被子植物花之间的气味具有趋同进 化趋势，其气味介于腐肉和粪便之间(Johnson \& Jürgens, 2010)。

(2)体内传播模式。体内传播即消化道传播，即 孢子植物被动物取食后, 其繁殖体随粪便排出, 从 而实现萌发和发育成新个体的过程。该种传播模式 在陆生无脊椎动物中较为常见, 如许多蛞蝓、蜗牛 和昆虫等(Boch et al, 2011, 2016)。Boch等(2011)用两 种地衣植物 (Lobaria pulmonaria 、 Physcia adscendens)对草食性的蜗牛进行投喂实验，从形态 学上证明 379 个粪球中 $29 \%$ 的地衣 Lobaria pulmonaria具有再生能力, 而 433 个粪球中 $40.9 \%$ 的 地衣Physcia adscendens具有再生能力, 这表明了地 衣碎片经过蜗牛肠道后能够存活。另外, Chen等 (2014)从五棱散尾鬼笔(Lysurus mokusin)的子实体 上提取的孢子表面是粗糙的，而从粪便中提取的此 真菌孢子表面是光滑的，并且还发现狍子通过动物 肠道后萌发率得到提高。经过体内传播的孢子有可 能还会进行二次传播，如有研究者推测鸟类传播与 植物具有共生关系的从枝菌根真菌, 是由于此真菌 的孢子附着在果实或种子上，也有可能是鸟类吞食 了一些以此真菌孢子为食的无脊椎动物 (蝶蚓等) (Harinikumar \& Bagyaraj, 1994), 但此过程可能不常 发生(Correia et al, 2019)。

还有一种非常特殊的体内传播方式一一组织 寄生，即某种真菌通过感染并寄生于蚂蚁体内从而 被传播。感染可能是通过真菌孢子与受食蚂蚁的角

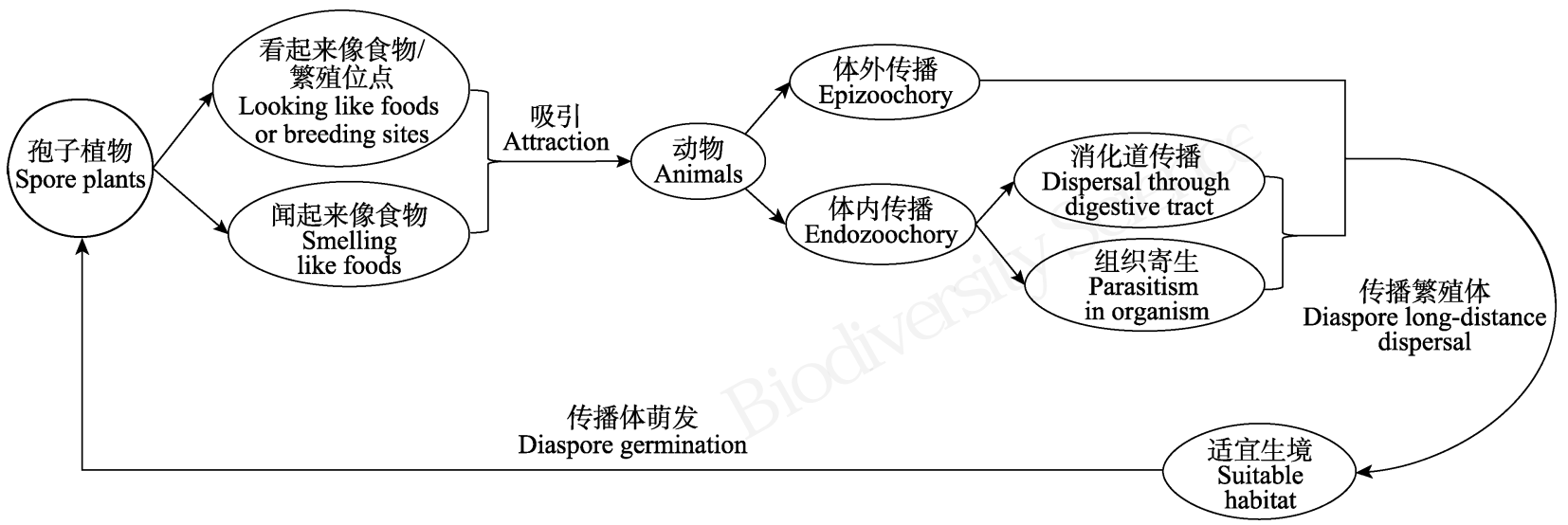

图1 动物与孢子植物的相互作用

Fig. 1 Interaction between animals and spore plants 
质层接触而发生(Hughes et al, 2011)。有研究发现在 泰国的常绿原生林中, 大多数被感染的蚂蚁在植株 上约 $25 \mathrm{~cm}$ 高处死亡, 该高度的温度和湿度变化小, 被认为有利于真菌孢子的发育、释放和传播 (Andersen et al, 2009)。然而真菌在蚂蚁体内生长期 间不会感染其他蚂蚁, 似乎也不会被其他蚂蚁发现 (Gracia et al, 2018)。在感染后的几周内, 蚂蚁会离 开巢穴, 爬上植株并用下颚附着在叶子或者植物其 他部位(树枝、刺或茎)上, 然后死亡(Andersen et al, 2009; Loreto et al, 2018), 被称为“僵尸蚂蚁”, 是真 菌对宿主行为进行操纵(Hughes et al, 2011), 类似于 某些特殊的寄生虫可以引起宿主的形态、生理和行 为的改变, 这有利于寄生虫发育、繁殖和传播 (Thomas et al, 2010)。然而感染蚂蚁的真菌与宿主之 间有一种奇特的现象, 即每一种真菌只会感染一种 蚂蚁(Loreto \& Hughes, 2016; Sakolrak et al, 2018)。

\section{2 传播距离}

传播距离通常是指从母源到一个新的基质之 间的距离。风媒是有效的长距离传播途径之一, 但 此途径只能在繁殖体处于植被冠层上方、被对流上 升气流的湍流携带时才会发生(Nathan et al, 2002)。 动物既能长距离传播又能短距离传播, Stubbs (1995) 发现螨虫对苔藓植物的粉芽具有传播作用, 它能将 粉芽从母源传到新的基质，传播距离为 $0.1-7.1 \mathrm{~cm}$ 。 同样作为无脊椎动物的蛞蝓也能够传播, 实验表明 其传播孢子植物繁殖体的平均距离为 $3.7 \mathrm{~cm}$, 最大 传播距离为 $23 \mathrm{~cm}$, 并且在干燥的树木上, 蛞蝓留 下的粘液痕迹可使繁殖体附着, 这是风媒无法实现 的(Kimmerer \& Young, 1995)。在脊椎动物中, 野猪 的刚毛能够附带苔藓繁殖体碎片, 它们每天的活动 范围可达 $5 \mathrm{~km}$, 可将碎片进行较长距离传播 (Heinken, 2001)。具有迁徙习性的行璚类的羽毛中 发现了大量苔藓植物的繁殖体, 它们从北半球的繁 殖地被携带到南半球, 实现了长距离传播(Lewis el at, 2014)。

孢子植物的传播距离也受某些因素影响, 如动 物的理毛行为(Kiviniem, 1996), 动物在用牙齿清理 或抖动毛发时会清除一些附着在皮毛上的繁殖体 (Heinken, 2000)。

\section{动物传播孢子植物的生态与进化意义}

虽然孢子植物的传播方式有多种, 但是对于风
媒传播而言，传播的距离与释放的高度和风速有关： 例如对于矮小的陆生蕨类植物, 绝大多数孢子的传 播距离小于 $2 \mathrm{~m}$, 对于较高的蒝类植物, 在封闭森 林的条件下传播 $100 \mathrm{~m}$, 开阔的环境下可达几公里 (Rose \& Dassler, 2017), 且狍子的沉积是随机的, 因此加剧了相互之间的竞争(da Silva et al, 2016)。 然而动物可以增强狍子植物传播的成功率, 比如扁 芝(Elfvingia applanata)需要寄生在死原木上，但死 原木在森林中的分布是零散的，在这种情况下，利 用以狍子为食的昆虫作为传播狍子的媒介可能比 利用空气传播更有效(Tuno,1999)。

孢子植物及其相关的动物类群是热带森林多 样性的重要组成部分(Ramsay \& Cairns, 2004)。许多 孢子植物类群作为重要的先锋群落, 分布极为广泛 (Deane-Coe \& Stanton, 2017), 不仅为栖息的动物提 供了大量的庇护场所和食物, 还涉及诸多的生态系 统服务(Davidson et al, 1990; Haines \& Renwick, 2009)。例如, 苔藓和蕨类植物有助于水源的过滤、 养分的储存以及固氮作用, 并且为植物的种子提供 萌发基质(Clark et al, 2005; DeLuca et al, 2007; Bay et al, 2013), 因此孢子植物被传播到新的生境有着 重要的生态意义。

由于某些孢子植物繁殖体的结构特点或萌发 的需求，使动植物之间存在密不可分的相互作用。 如蕨类植物的孢子储存在孢子囊中, 孢子囊盖起着 保护作用，阻碍了风媒对孢子的传播，而以孢子为 食的夜蛾科幼虫能够打破这个阻碍(Nervo et al, 2011), 幼虫羽化后可能带走狍子; Lim (1977)发现 某种灵芝属(Ganoderma)孢子不经过苍蝇幼虫的肠 道就不能萌发。由此可见, 动物通过对孢子植物的 取食与传播，两者间可能存在协同进化的关系。

\section{研究展望}

国内对于孢子植物与动物的关系研究甚少。 典型的例子是食菌性昆虫对于五棱散尾鬼笔孢子 的传播, 国外主要研究了小型动物以及一些大型哺 乳动物对孢子植物繁殖体的传播作用, 然而这些研 究主要是一些描述性的内容且大多为探究单方面 传播途径, 但动物对狍子植物的传播可能是多途径 同时进行。为了进一步了解动物对孢子植物的传播 作用, 加强生物多样性保护, 还需要进行以下研究: 
(1)动物对于孢子植物的多途径传播。由于动物 形态结构的特殊性，有可能进行消化道传播的同时 体表也携带繁殖体，且消化道滞留时间与体表携带 时间不同，使繁殖体被传播到不同生境，从而能够 扩大孢子植物的传播范围。

(2)动物与孢子植物互惠关系的生态机制。目前 对于孢子植物的传播主要是描述性的内容, 然而在 各类传播模式下, 动物类群对孢子植物繁殖体传播 的有效性如何? 孢子植物给动物提供的效益如 何？孢子植物与动物的关系是否符合 Schupp 等 (2017)提出的动物与种子植物互惠的关系? 建议今 后的研究多关注动物与孢子植物的多种互惠关系。

(3)不同尺度上的研究。从传播者对栖息地中特 定物种基因流动、物种更新的贡献, 到传播者对物 种远距离传播促进物种多样性形成(协同进化)、对 维系生态系统稳定的贡献等尺度开展，探讨这类问 题有助于理解物种在生态系统中的生态意义。

(4)孢子植物和动物关系的形成、维持及将来的 进化趋势也值得研究，孢子植物释放的视觉、嗅觉 信息对动物的吸引作用的识别机制、味觉信息对动 物的识别、防御或接受信息的过程值得未来探索。

致谢: 白炎培、朱遵燕、周帅岭、林锦煌等在论文 初稿形成过程中给予了帮助，审稿专家对该论文提 出了宝贵建议，谨致谢忱。

\section{ORCID}

王琴 (iD) https://orcid.org/0000-0002-0921-3681

向左甫 (iD https://orcid.org/0000-0001-6133-3261

\section{参考文献}

Andersen SB, Gerritsma S, Yusah KM, Mayntz D, Hywel-Jones NL, Billen J, Boomsma JJ, Hughes DP (2009) The life of a dead ant: The expression of an adaptive extended phenotype. The American Naturalist, 174, 424-433.

Arosa ML, Ramos JA, Quintanilla LG, Brown D (2010) First report of fern (Culcita macrocarpa) spore consumption by a small mammal (Apodemus sylvaticus). Mammalian Biology, 75, 115-121.

Arosa ML, Ramos JA, Valkenburg T, Ceia R, Laborda H, Quintanilla LG, Heleno R (2009) Fern feeding ecology of the Azores bullfinch Pyrrhula murina: The selection of fern species and the influence of nutritional composition in fern choice. Ardeola, 56, 71-84.

Bailey RH, James PW (1979) Birds and the dispersal of lichen propagules. The Lichenologist, 11, 105-106.

Barbé M, Chavel ÉE, Fenton NJ, Imbeau L, Mazerolle MJ, Drapeau P, Bergeron Y (2016) Dispersal of bryophytes and ferns is facilitated by small mammals in the boreal forest. Ecoscience, 23, 67-76.

Bay G, Nahar N, Oubre M, Whitehouse MJ, Wardle DA, Zackrisson O, Nilsson MC, Rasmussen U (2013) Boreal feather mosses secrete chemical signals to gain nitrogen. New Phytologist, 200, 54-60.

Bisang I, Hedenäs L (2015) Mass-occurrence of springtails on Tortula cernua (Huebener) Lindb.: A field-observation of possible animal-mediated fertilization. Journal of Bryology, 37, 339-341.

Boch S, Berlinger M, Prati D, Fischer M (2016) Is fern endozoochory widespread among fern-eating herbivores? Plant Ecology, 217, 13-20.

Boch S, Prati D, Werth S, Rüetschi J, Fischer M (2011) Lichen endozoochory by snails. PLoS ONE, 6, e18770.

Bråthen KA, González VT, Iversen M, Killengreen S, Ravolainen VT, Ims RA, Yoccoz NG (2007) Endozoochory varies with ecological scale and context. Ecography, 30, 308-320.

Chen G, Zhang RR, Liu Y, Sun WB (2014) Spore dispersal of fetid Lysurus mokusin by feces of mycophagous insects. Journal of Chemical Ecology, 40, 893-899.

Chmielewski MW, Eppley SM (2019) Forest passerines as a novel dispersal vector of viable bryophyte propagules. Proceedings of the Royal Society B: Biological Sciences, 286, 20182253.

Clark KL, Nadkarni NM, Gholz HL (2005) Retention of inorganic nitrogen by epiphytic bryophytes in a tropical montane forest. Biotropica, 37, 328-336.

Correia M, Heleno R, da Silva LP, Costa JM, Rodríguez-Echeverría S (2019) First evidence for the joint dispersal of mycorrhizal fungi and plant diaspores by birds. New Phytologist, 222, 1054-1060.

da Silva LP, Pereira Coutinho A, Heleno RH, Tenreiro PQ, Ramos JA (2016) Dispersal of fungi spores by non-specialized flower-visiting birds. Journal of Avian Biology, 47, 438-442.

Davidson AJ, Harborne JB, Longton RE (1990) The acceptability of mosses as food for generalist herbivores, slugs in the Arionidae. Botanical Journal of the Linnean Society, 104, 99-113.

Deane-Coe KK, Stanton D (2017) Functional ecology of cryptogams: Scaling from bryophyte, lichen, and soil crust traits to ecosystem processes. New Phytologist, 213, 993-995.

DeLuca TH, Zackrisson O, Gentili F, Sellstedt A, Nilsson MC (2007) Ecosystem controls on nitrogen fixation in boreal feather moss communities. Oecologia, 152, 121-130. 
Fischer OA, Vícha R (2003) Blowflies (Diptera, Calliphoridae) attracted by Phallus impudicus (Phallaceae) and Stapelia grandiflora (Asclepiadaceae). Biologia-Section Zoology, 58, 995-998.

Gracia ES, de Bekker C, Hanks EM, Hughes DP (2018) Within the fortress: A specialized parasite is not discriminated against in a social insect society. PLoS ONE, 13, e0193536.

Gressitt JL, Samuelson GA, Vitt DH (1968) Moss growing on living Papuan moss-forest weevils. Nature, 217, 765-767.

Haines WP, Renwick JAA (2009) Bryophytes as food: Comparative consumption and utilization of mosses by a generalist insect herbivore. Entomologia Experimentalis et Applicata, 133, 296-306.

Harinikumar KM, Bagyaraj DJ (1994) Potential of earthworms, ants, millipedes, and termites for dissemination of vesicular-arbuscular mycorrhizal fungi in soil. Biology and Fertility of Soils, 18, 115-118.

Heinken T (2000) Dispersal of plants by a dog in a deciduous forest. Botanische Jahrbücher für Systematik, Pflanzengeschichte und Pflanzengeographie, 122, 449-467.

Heinken T, Lees R, Raudnitschka D, Runge S (2001) Epizoochorous dispersal of bryophyte stem fragments by roe deer (Capreolus capreolus) and wild boar (Sus scrofa). Journal of Bryology, 23, 293-300.

Hughes DP, Andersen SB, Hywel-Jones NL, Himaman W, Billen J, Boomsma JJ (2011) Behavioral mechanisms and morphological symptoms of zombie ants dying from fungal infection. BMC Ecology, 11, 13.

Johnson SD, Jürgens A (2010) Convergent evolution of carrion and faecal scent mimicry in fly-pollinated angiosperm flowers and a stinkhorn fungus. South African Journal of Botany, 76, 796-807.

Kaiser R (2006) Flowers and fungi use scents to mimic each other. Science, 311, 806-807.

Kimmerer RW, Young CC (1995) The role of slugs in dispersal of the asexual propagules of Dicranum flagellare. The Bryologist, 98, 149-153.

Kimmerer RW, Young CC (1996) Effect of gap size and regeneration niche on species coexistence in bryophyte communities. Bulletin of the Torrey Botanical Club, 123, 16-24.

Kiviniemi K (1996) A study of adhesive seed dispersal of three species under natural conditions. Acta Botanica Neerlandica, 45, 73-83.

Lewis LR, Behling E, Gousse H, Qian E, Elphick CS, Lamarre JF, Bêty J, Liebezeit J, Rozzi R, Goffinet B (2014) First evidence of bryophyte diaspores in the plumage of transequatorial migrant birds. PeerJ, 2, e424.

Lim TM (1977) Production, germination and dispersal of basidiospores of Ganoderma pseudoferreum on Hevea. Journal of the Rubber Research Institute of Malaysia, 25, 93-99.

Loreto RG, Araújo JPM, Kepler RM, Fleming KR, Moreau CS,
Hughes DP (2018) Evidence for convergent evolution of host parasitic manipulation in response to environmental conditions. Evolution, 72, 2144-2155.

Loreto RG, Hughes DP (2016) Disease dynamics in ants: A critical review of the ecological relevance of using generalist fungi to study infections in insect societies. Advances in Genetics, 94, 287-306.

Luo JX (1977) What are bryophytes. The Plant Journal, (4), 38-40. (in Chinese) [罗健馨 (1977) 什么是苔藓植物. 植 物杂志, (4), 38-40.]

Maciel-Silva AS, Pôrto KC (2014) Reproduction in bryophytes. In: Reproductive Biology of Plants (eds Ramawat KG, Mérillon JM, Shivanna KR), pp. 57-84. CRC Press, Boca Raton.

Marino P, Raguso R, Goffinet B (2009) The ecology and evolution of fly dispersed dung mosses (Family Splachnaceae): Manipulating insect behaviour through odour and visual cues. Symbiosis, 47, 61-76.

Mishler BD, Newton AE (1988) Influences of mature plants and desiccation on germination of spores and gametophyticfragments of Tortula. Journal of Bryology, 15, 327-342.

Nathan R, Katul GG, Horn HS, Thomas SM, Oren R, Avissar R, Pacala SW, Levin SA (2002) Mechanisms of long-distance dispersal of seeds by wind. Nature, 418, 409-413.

Nervo MH, Windisch PG, Seibert S (2011) Herbivory on Pecluma pectinatiformis (L.) Price (polypodiopsida) by caterpillars of Argyrosticta Hübner (Lepidoptera)—A possible case of mimicry? American Fern Journal, 101, 317-318.

Pauliuk F, Müller J, Heinken T (2011) Bryophyte dispersal by sheep on dry grassland. Nova Hedwigia, 92, 327-341.

Ramsay HP, Cairns A (2004) Habitat, distribution and the phytogeographical affinities of mosses in the Wet Tropics bioregion, north-east Queensland, Australia. Cunninghamia, 8, 371-408.

Rose JP, Dassler CL (2017) Spore production and dispersal in two temperate fern species, with an overview of the evolution of spore production in ferns. American Fern Journal, 107, 136-155.

Roy BA (1994) The use and abuse of pollinators by fungi. Trends in Ecology \& Evolution, 9, 335-339.

Rudolphi J (2009) Ant-mediated dispersal of asexual moss propagules. The Bryologist, 112, 73-79.

Sakolrak B, Blatrix R, Sangwanit U, Kobmoo N (2018) Experimental infection of the ant Polyrhachis furcata with Ophiocordyceps reveals specificity of behavioural manipulation. Fungal Ecology, 33, 122-124.

Salzmann CC, Brown A, Schiestl FP (2006) Floral scent emission and pollination syndromes: Evolutionary changes from food to sexual deception. International Journal of Plant Sciences, 167, 1197-1204. 
Schupp EW, Jordano P, Gómez JM (2017) A general framework for effectiveness concepts in mutualisms. Ecology Letters, 20, 577-590.

Stephens RB, Rowe RJ (2020) The underappreciated role of rodent generalists in fungal spore dispersal networks. Ecology, 101, e02972.

Stubbs CS (1995) Dispersal of soredia by the oribatid mite, Humerobates arborea. Mycologia, 87, 454-458.

Thomas F, Poulin R, Brodeur J (2010) Host manipulation by parasites: A multidimensional phenomenon. Oikos, 119, 1217-1223.

Tuno N (1998) Spore dispersal of Dictyophora fungi (Phallaceae) by flies. Ecological Research, 13, 7-15.

Tuno N (1999) Insect feeding on spores of a bracket fungus, Elfvingia applanata (Pers.) Karst. (Ganodermataceae,
Aphyllophorales). Ecological Research, 14, 97-103.

van Tooren BF, During HJ (1988) Viable plant diaspores in the guts of earthworms. Acta Botanica Neerlandica, 37, 181-185.

Wilkinson DM, Lovas-Kiss A, Callaghan DA, Green AJ (2017) Endozoochory of large bryophyte fragments by waterbirds. Cryptogamie, Bryologie, 38, 223-228.

Xiang ZF (2020) A review on the socioecology of snub-nosed monkeys. Chinese Bulletin of Life Sciences, 32, 692-703. (in Chinese with English abstract) [向左甫 (2020) 金丝猴 社会生态学研究进展. 生命科学, 32, 692-703.]

(责任编委: 肖治术 责任编辑: 时意专) 